\title{
31. ORGANIC FACIES VARIATIONS IN SEDIMENTS FROM LEG 84, OFF GUATEMALA ${ }^{1}$
}

\author{
Deborah Gilbert and Robert Cunningham, Exxon Production Research Company, Houston, Texas ${ }^{2}$
}

\begin{abstract}
Continental slope samples offshore Guatemala contain organic matter derived from both terrestrial and marine sources. Upper Pleistocene samples are generally amorphous-rich, with TOCs averaging $2.4 \%$. Pliocene and Miocene sediments contain varying amounts of terrestrial material that increase in proportion down toward the base of the slope. TOCs average $0.93 \%$. The samples are currently immature for the generation of liquid hydrocarbons.
\end{abstract}

\section{INTRODUCTION}

This work expands our study of the distribution of the types and amounts of organic matter along the Guatemalan continental slope begun with samples from Leg 67. The objectives of this study are to determine how much organic matter was preserved on the slope, whether it was derived from terrestrial or marine sources, and to evaluate the hydrocarbon source potential of the recovered section.

As shown on Figure 1, the samples in this study are from positions along the upper and middle Guatemalan slope and at the base of the slope, $550 \mathrm{~m}$ above the Trench floor.

\section{TYPE AND AMOUNT OF ORGANIC MATTER}

The total organic carbon (TOC) content of the samples was measured by a Leco carbon analyzer, after the samples had been treated with dilute $\mathrm{HCl}$ to remove the carbonate minerals. The different organic matter types were visually identified under transmitted light using the classification system of Masran and Pocock (1981). Interpretation of hydrocarbon potential was aided by RockEval pyrolysis (Espitalié, et al., 1977).

\section{Site 567 (at $5500 \mathrm{~m}$ water depth)}

Hole 567A sediments are from the base of the Guatemalan slope and are the deepest and most seaward of those recovered on the Leg 84 transect. Lower Miocene green mudstone deposits contain almost exclusively terrestrial remains with only minor amounts of algal and amorphous organic matter. Total organic carbon values average $0.75 \%$. The one exception is Sample 567A-3-5, 110-117 cm, which contains $95 \%$ amorphous kerogen and a TOC of $2.75 \%$. Although there is a discrepancy with Sample 567A-6-3, 120-127 cm, which has an anomalously high hydrogen index, hydrogen indexes determined by Rock-Eval pyrolysis correlate with the visual kerogen descriptions, indicating an essentially gas-prone, Type III kerogen.

\footnotetext{
${ }^{1}$ von Huene, R., Aubouin, J., et al., Init. Repts. DSDP, 84: Washington (U.S. Govt. Printing Office).

Address: Exxon Production Research Company, P.O. Box 2189, Houston, TX 77001.
}

\section{Site 569 (at $2744 \mathrm{~m}$ water depth)}

Site 569 sediments are from the midslope area, $3200 \mathrm{~m}$ above the Middle America Trench floor. Recovered upper Pleistocene green muds have a predominantly terrestrial organic facies, with some evidence of redeposition and reworking of the sediments reflected in the organic matter assemblages. Total organic carbon values are fair, averaging $0.71 \%$. Upper Miocene and Oligocene green mudstones have slightly higher organic carbon values (average-1.0\%). Organic matter types vary among the samples, although amorphous material of unknown origin is the predominant organic type.

Interestingly, hydrogen indexes for the entire suite of samples analyzed show little variation. The samples average $266 \mathrm{mg} \mathrm{HC} / \mathrm{g} \mathrm{C}$ and would be described on a Van Krevelen diagram as a mix of Types II and III kerogen.

\section{Site 568 (at $2101 \mathrm{~m}$ water depth)}

Site 568 is on the upper Guatemalan slope, $4000 \mathrm{~m}$ above the Trench floor axis. The upper Pleistocene hemipelagic sediments recovered at Site 568 contain some of the richest samples recovered on this leg. Total organic carbon contents average $2.41 \%$. Although charred plant remains were noted in several of the samples, amorphous kerogen of possible marine derivation is the dominant organic matter type. Pliocene and Miocene green mudstones contain less organic carbon $(0.94 \%$ TOC) and have an increasing terrestrial component with depth. Two of the samples $(568-36-4,126-135 \mathrm{~cm}$ and 564-41-4, $120-127 \mathrm{~cm}$ ) contain radiolarian remains in quantities not normally seen in our standard kerogen studies. This may indicate a highly productive water mass above the site of deposition.

The pyrolysis results from these samples were surprising. Despite their higher terrestrial content, hydrogen indexes from the Pliocene and Miocene samples (average $-263 \mathrm{mg} \mathrm{HC} / \mathrm{g} \mathrm{C}$ ) were higher than those from the upper Pleistocene (average- $95 \mathrm{mg} \mathrm{HC} / \mathrm{g} \mathrm{C}$ ). Reworked organic matter in the upper Pleistocene samples may have masked the hydrogen contribution of the amorphous kerogen or the amorphous kerogen itself may have been oxidized. 


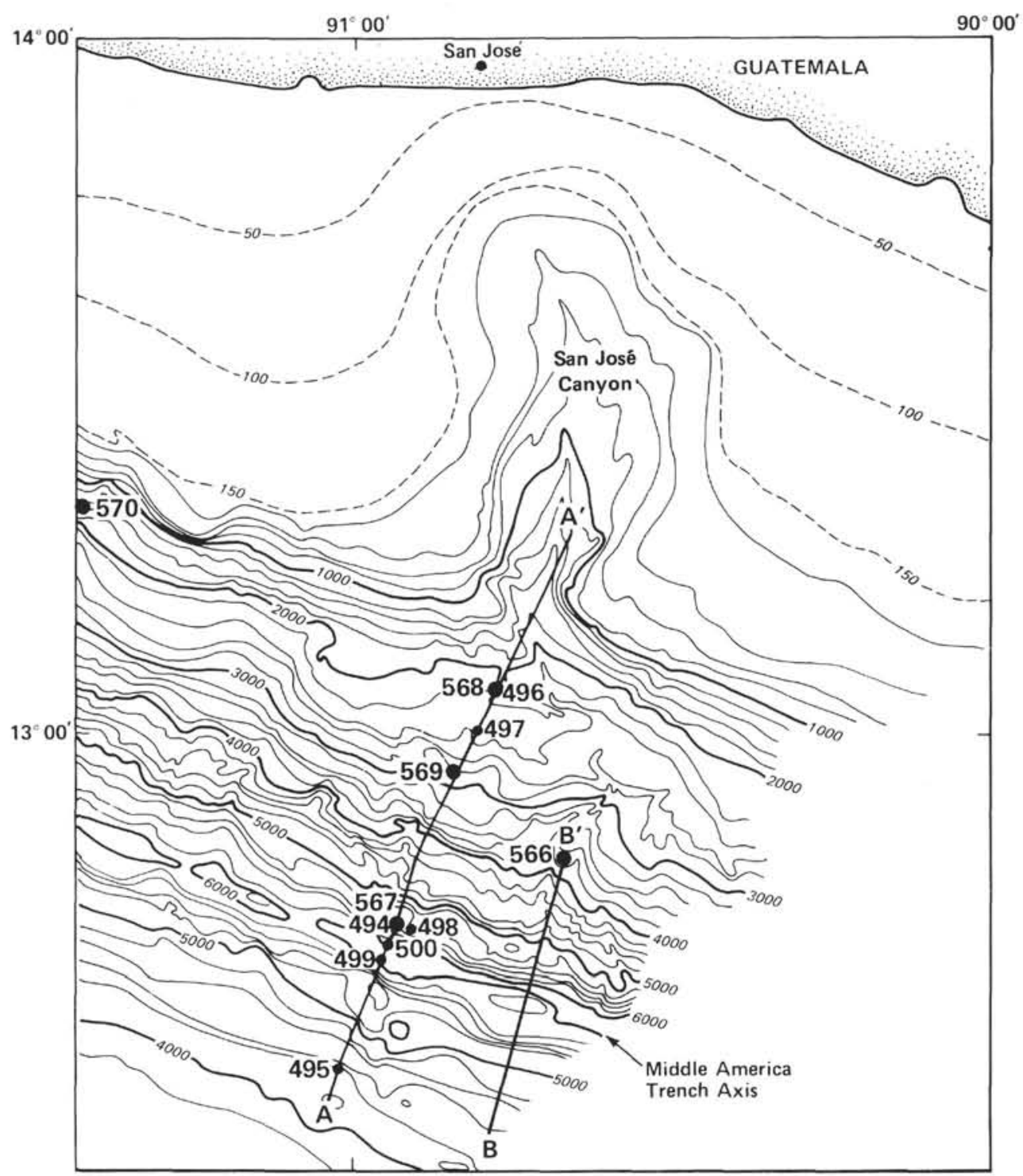

Figure 1. Location of DSDP Leg 84 sites of fshore Guatemala.

\section{Site 570 (at $1698 \mathrm{~m}$ water depth)}

Site 570 in the upper Guatemalan slope is shallowest of the sites drilled on the Leg 84 transect. Only one upper Miocene sample was analyzed. It was organically enriched $($ TOC $=3.32 \%)$ and consisted of amorphous organic matter of possible marine derivation.

\section{THERMAL ALTERATION}

Thermal alteration indexes (TAI) were determined from spore and pollen color (Staplin, 1969). The TAIs in these samples range from 1.3 to 2.0 (Table 1), indicating that the samples are immature for hydrocarbon generation.

T-Max values from pyrolysis corroborate the immaturity of the samples (Table 1). T-Max is the temperature at the peak of hydrocarbon generation during pyrolysis (Espitalié et al., 1977). Typical T-Max values for immature samples are below $435^{\circ} \mathrm{C}$.

\section{PYROLYSIS RESULTS}

Pyrograms generated from Rock-Eval pyrolysis commonly display three peaks $-S_{1}, S_{2}$, and $S_{3}$. The $S_{1}$ peak corresponds to the amount of free hydrocarbons in the rock. The $\mathrm{S}_{2}$ peak reflects the amount of hydrocarbons generated as the kerogen is heated and cracked. The $\mathrm{S}_{3}$ peak corresponds to the amount of $\mathrm{CO}_{2}$ released as the kerogen is cracked. T-Max, an indication of the maturation state of the kerogen, is measured at the peak of $\mathrm{S}_{2}$ generation (Espitalié et al., 1977).

Many of the pyrograms from the Leg 84 samples have a second $\mathrm{S}_{2}$ peak with a T-Max of 500 to $550^{\circ} \mathrm{C}$ (Fig. 2). We interpret this second $S_{2}$ peak as being derived from oxidized and reworked kerogen. The high T-Max values indicate an abnormally high maturation state (Table 1 ).

While the hydrogen indexes in Table 1 were determined solely from the first $S_{2}$ peak, the oxygen indexes are abnormally high, in response to the abundance of oxidized material. 
Table 1. Age, total organic carbon, organic matter types, and pyrolysis results from Leg 84 samples.

\begin{tabular}{|c|c|c|c|c|c|c|c|c|c|c|c|c|c|c|}
\hline \multirow{2}{*}{$\begin{array}{c}\text { Sample } \\
\text { (interval in } \mathrm{cm} \text { ) }\end{array}$} & \multirow{2}{*}{$\begin{array}{l}\text { Sub-bottom } \\
\text { depth } \\
\text { (m) }\end{array}$} & \multirow[b]{2}{*}{ TOC $(\%)$} & \multirow[b]{2}{*}{ TAI } & \multicolumn{7}{|c|}{ Organic matter types ${ }^{\mathrm{a}}$} & \multirow[b]{2}{*}{$\mathrm{Age}^{\mathrm{b}}$} & \multirow[b]{2}{*}{ HI } & \multirow[b]{2}{*}{ OI } & \multirow{2}{*}{$\begin{array}{c}\text { T-Max } \\
\left({ }^{\circ} \mathrm{C}\right)\end{array}$} \\
\hline & & & & $\mathrm{AM}$ & SA & BT & PS & ST & I & RB & & & & \\
\hline \multicolumn{15}{|l|}{ Base of slope } \\
\hline $567 \mathrm{~A}-3-5,110-117$ & 5751 & 2.75 & 1.3 & 95 & - & - & - & - & - & - & LM & 289 & 472 & $415 / 537$ \\
\hline $567 \mathrm{~A}-6-3,120-127$ & 5777 & 0.42 & 1.3 & 5 & - & 10 & 20 & 55 & 10 & - & LM & 652 & 2,021 & $435 / 537$ \\
\hline 567A-9-5, 120-127 & 5808 & 0.93 & 1.3 & 10 & 5 & 5 & 10 & 60 & 10 & - & LM & 16 & 777 & 422 \\
\hline $567 \mathrm{~A}-12-4,110-120$ & 5837 & 0.79 & 1.7 & 5 & - & - & 10 & 75 & 10 & - & LM & 15 & 918 & 425 \\
\hline $567 \mathrm{~A}-14-1,120-127$ & 5846 & 0.84 & 1.7 & 10 & - & 10 & - & 60 & 20 & - & LM & 178 & 234 & $413 / 500$ \\
\hline \multicolumn{15}{|l|}{ Mid-slope } \\
\hline $569-1-3,120-129$ & 2800 & 0.66 & 1.3 & 5 & - & - & 5 & 80 & 10 & - & UP & 278 & 663 & $337 / 525$ \\
\hline $569-11-1,120-130$ & 2888 & 0.76 & 1.7 & 20 & - & - & 10 & 50 & 10 & 10 & UP & 353 & 656 & $420 / 520$ \\
\hline $569-13-3,134-140$ & 2910 & 0.93 & 1.7 & 95 & - & - & - & - & - & - & UM & 243 & 748 & $418 / 537$ \\
\hline $569-17-5,127-136$ & 2951 & 0.68 & 1.3 & - & - & - & 10 & 80 & 10 & - & UM & 223 & 267 & $361 / 537$ \\
\hline $569-23-3,110-117$ & 3006 & 1.15 & 1.3 & 95 & - & - & - & 5 & - & - & UM & 252 & 275 & $393 / 550$ \\
\hline $569-26-3,140-149$ & 3034 & 1.23 & 1.3 & 50 & - & - & 10 & 30 & 10 & - & UO & 250 & 513 & $390 / 550$ \\
\hline \multicolumn{15}{|l|}{ Upper slope } \\
\hline $568-4-4,120-127$ & 2058 & 1.66 & 1.3 & 90 & - & - & - & 5 & 5 & - & UPI & 186 & 531 & 430 \\
\hline $568-7-1,120-127$ & 2083 & 3.16 & 1.3 & 95 & - & - & - & - & - & - & UPI & 198 & 394 & 415 \\
\hline $568-10-1,120-127$ & 2113 & 2.58 & 1.3 & 95 & - & - & - & - & 5 & - & UPI & 46 & 441 & 419 \\
\hline $568-13-2,14-24$ & 2141 & 2.38 & 1.3 & 50 & - & - & - & 30 & 20 & - & UPI & 48 & 453 & 417 \\
\hline $568-17-5,123-131$ & 2184 & 2.83 & 1.3 & 50 & - & - & - & 20 & 10 & 20 & UPI & 48 & 401 & 410 \\
\hline $568-19-5,120-130$ & 2194 & 1.84 & 1.3 & 95 & - & - & - & - & 5 & - & UPI & 45 & 434 & 420 \\
\hline $568-22-4,122-131$ & 2231 & 0.93 & 1.3 & 80 & - & - & 5 & 5 & - & 10 & LP-MM & 561 & 325 & $415 / 537$ \\
\hline $568-25-3,120-129$ & 2262 & 0.82 & 1.3 & 10 & - & - & 30 & 50 & 10 & - & LP-MM & 269 & 584 & $409 / 550$ \\
\hline $568-28-5,120-129$ & 2293 & 1.08 & 1.3 & 80 & - & - & 5 & 10 & 5 & - & MM & 200 & 676 & 417 \\
\hline $568-33-6,115-125$ & 2341 & 1.00 & 1.3 & 55 & - & - & 5 & 30 & 10 & - & MM & 208 & 836 & 418 \\
\hline $568-36-4,126-135$ & 2368 & 0.83 & 1.7 & 80 & - & - & - & 10 & 10 & - & MM & 197 & 667 & $370 / 550$ \\
\hline $568-41-4,120-127$ & 2416 & 0.96 & 2.0 & 20 & - & - & 5 & 60 & 10 & 5 & LM & 1,471 & 454 & $381 / 537$ \\
\hline \multicolumn{15}{|l|}{ Upper slope } \\
\hline $570-32-5,120-127$ & 2023 & 3.32 & 1.3 & 95 & - & - & - & - & - & - & UM & 365 & 257 & 418 \\
\hline
\end{tabular}

Note: $\mathrm{HI}=$ hydrogen index; $\mathrm{OI}=$ oxygen index.

${ }^{a}$ Kerogen description: AM-amorphous; SA-structured aqueous; BT-biodegraded terrestrial; PS-pollen and spores; ST-structured terrestrial;

I-inert; RB-round bodies; - = 0\%.
Age: UPI-upper Pleistocene; UP, LP-upper, lower Pliocene; UM, MM, LM-upper, middle, lower Miocene; UO-upper Oligocene.

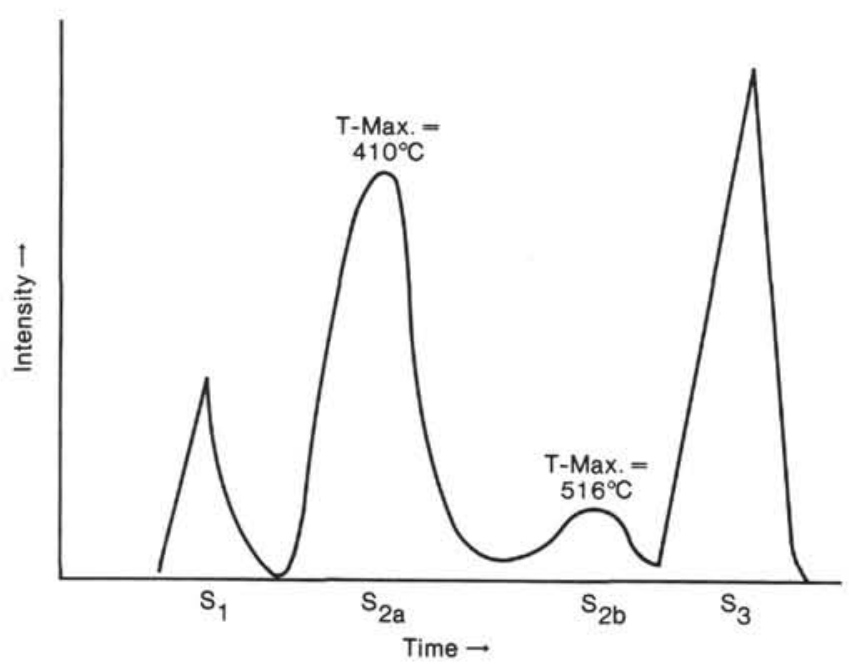

Figure 2. Typical pyrogram from Leg 84 samples.

Double $S_{2}$ peaks have been reported in DSDP samples previously. Boutefu and Labofina (1976) reported $\mathrm{S}_{2}$ peaks from the Moroccan Basin with a small "shoulder" between $S_{1}$ and $S_{2}$ peaks. They interpreted this shoulder with T-Max values between 300 and $400^{\circ} \mathrm{C}$ as being derived from very immature kerogen. $\mathrm{A}$ wide range of higher T-Max values from the main portion of the $\mathrm{S}_{2}$ peak was attributed to reworked kerogen.

\section{DISCUSSION}

Although Leg 84 sediments show more variability in total organic carbon contents and organic matter types than had been noted on Leg 67, similarities are present between the two Guatemalan studies as well as between Leg 84 samples and those recovered from the continental slope offshore Mexico on Leg 66.

Guatemalan slope sediment analyzed from Leg 67 by Summerhayes and Gilbert (1982), regardless of their age consist predominantly of marine-derived amorphous organic matter with TOCs of up to $4.8 \%$. Upper Pleistocene sediments at Site 568 are similar to those recovered at Site 496 on Leg 67, however variability and more terrestrial matter exist in the Pliocene and Miocene samples along the Guatemalan slope then previously noted.

The terrestrial component in Pliocene and Miocene samples on the upper slope averages $43 \%$, on the midslope, $50 \%$, and at the base of the slope, $72 \%$. Summerhayes and Gilbert (1982) reported 5\% terrestrial material in distal slope sediments and $12 \%$ in proximal slope sediments recovered on Leg 67. The increased terrestrial content may simply be a function of more detailed sampling of the Pliocene-Miocene interval on Leg 84 . 
Alternatively, Pliocene-Miocene sediments analyzed from Leg 67 may have contained masses of amorphous-rich sediments deposited further upslope within the oxygen minimum. Regardless of the cause, the increased terrestrial contents of the Leg 84 sediments supports the observation made by Summerhayes and Gilbert (1982) that these sites were deposited in oxygenated waters below the oxygen minimum.

The lower Miocene samples recovered from the base of the slope in Hole 567A have total organic carbon contents of less than $1.0 \%$ and consist of predominantly terrestrially derived kerogen. The nature of this assemblage is similar to that noted by Summerhayes and Gilbert (1981) at Site 488 on the base of the Mexican continental slope. At Site 488 high terrestrial contents were attributed to (1) high oxygen contents during the early Miocene and (2) introduction and deposition of terrestrial material by slumps, slides, or turbidity currents down the Middle America Trench. These same conditions are likely to be responsible for the lower Miocene assemblage in Hole 567A.

\section{CONCLUSIONS}

The variations in organic facies along the continental slope offshore Guatemala reflect both the source of the organic matter and conditions in the water column. Late Pleistocene sediments at Site 568 along the upper slope are organically enriched (average $2.4 \%$ TOC) and contain amorphous, possibly marine-derived, organic matter. The sediments are similar to those recovered at Site 496 on Leg 67.

Terrestrially derived organic matter increases in Pliocene and Miocene sediments down the slope. With the exception of the Site 570 sample, TOCs average $0.93 \%$. The lower total organic carbon values and increased ter- restrial content may reflect deposition in an oxidizing water column.

Many of the samples have the potential to generate oil and gas hydrocarbons. The samples are currently immature and incapable of generating liquid hydrocarbons.

\section{ACKNOWLEDGMENTS}

We thank Exxon Production Research Company for the permission to publish this work. TOCs were analyzed by M. S. Bisotooni, and Rock-Eval pyrolysis was carried out by K. Hahn and V. J. Cleboski. D. Gilbert made the kerogen analyses and determined thermal alteration indexes. P. M. Kroopnick and D. L. Johnson reviewed the manuscript.

\section{REFERENCES}

Boutefu, A., Labofina, S. A., 1976. Pyrolysis study of organic matter from Deep Sea Drilling Project Sites 370 (Leg 41), 415, and 416 (Leg 50). In Lancelot, Y., E. Winterer, et al., Init. Repts. DSDP, 50: Washington (U.S. Govt. Printing Office), 555-567.

Espitalié, J., Tissot, B., Mennig, J. J., and Leplat, P., 1977. Source rock characterization method for petroleum exploration. Proc. 1977 Offshore Technol. Conf., 3:439-443.

Masran, Th. C., and Pocock, S.A.J., 1981. The classification of plantderived particulate organic matter in sedimentary rocks. In Brooks J. (Ed.), Organic Maturation Studies and Fossil Fuel Exploration: Academic Press (New York), pp. 145-149.

Staplin, F. L., 1969. Sedimentary organic matter, organic metamorphism, and oil and gas occurrence. Bull. Can. Petrol. Geol., 17: $47-66$.

Summerhayes, C. P., and Gilbert, D., 1981. Distribution, origin, and hydrocarbon potential of organic matter in sediments from the $\mathrm{Pa}$ cific margin of southern Mexico. In Watkins, J. S., Moore, J. C., et al., Init. Repts. DSDP, 66: Washington (U.S. Govt. Printing Office), 541-546.

1982. Distribution, origin, and hydrocarbon potential of organic matter in sediments from the Pacific margin of Guatemala In Aubouin, J., von Huene, R., et al., Init. Repts. DSDP, 67: Washington (U.S. Govt. Printing Office), 595-599.

Date of Initial Receipt: 24 October 1983

Date of Acceptance: 29 October 1983 